\title{
REALISASI PRINSIP KERJA SAMA DALAM PERCAKAPAN MASYARAKAT SEDULUR SIKEP PATI
}

\author{
Euis Kurniasih \\ Fakultas Bahasa dan Seni Universitas Indraprasta PGRI \\ Jl. Nangka 58 Tanjung Barat, Jakarta Selatan, 12530 \\ euis99@gmail.com
}

\begin{abstract}
Abstrak
Penelitian ini bertujuan untuk mengetahui realisasi prinsip kerja sama dalam percakapan masyarakat sedulur sikep di Pati. Metode yang digunakan dalam penelitian ini adalah deskriptif kualitatif. Sumber data yang berasal dari percakapan masyarakat sedulur sikep didapatkan melalui studi lapangan dengan teknik pencatatan dan perekaman. Teori prinsip kerjasama Grice digunakan untuk menganalisis percakapan dan realisasinya dibagi kedalam pemenuhan dan pelanggaran prinsip kerja sama. Hasil penelitian ini menunjukkan bahwa realisasi pemenuhan percakapan dalam masyarakat sedulur sikep memenuhi empat maksim yaitu maksim kuantitas, kualitas, relasi, dan cara. Hal ini menunjukkan bahwa percakapan mereka sesuai dengan fakta, bahasanya singkat, jelas serta respon antarpenutur yang relevan. Realisasi pelanggaran prinsip kerjasama meliputi maksim kuantitas, relasi dan cara. Pelanggaran ini menunjukkan bahwa tuturan yang diungkapkan masyarakat sedulur sikep mengandung informasi yang diulang sebagai bentuk penegasan, mengandung ambigu dan informasi yang tidak relevan. Ketiadaan pelanggaran maksim kualitas menunjukkan karakteristik dasar masyarakat sikep yang jujur.
\end{abstract}

Kata Kunci: prinsip kerja sama, maksim Grice, Sedulur Sikep Pati

\begin{abstract}
This research aims to reveal the realization of cooperative principles on the conversation of Sedulur Sikep society in Pati. The method use is descriptive qualitative approach. The data source are from the conversation of Sedulur Sikep collected by fieldwork with notetaking and recording techniques. The theory of Grice cooperative principles is used to analyse the cooperative principles in the conversation which categorized into compliance and violation. The result shows that the compliance maxim entails quantity, quality, relation and manner. It indicates that their conversation is corresponding to the fact, the language used is brief and the turn taking of the speaker is relevant. In the other side, the realization of the nonobservance covers quantity, relation and manner maxim. The non-observance of the cooperative principles represent to the speech act conveyed by their society has the repetitive information, ambiguity and irrelevant information. The absence of the cooperative principle violation shows the basic character of the society which is always honest.
\end{abstract}

Keywords: cooperative principles, Grice maxim, Sedulur Sikep Pati

\section{PENDAHULUAN}

Masyarakat Sedulur Sikep atau yang lebih dikenal oleh masyarakat luas sebagai komunitas Samin, memiliki karakter kemasyarakatan yang berbeda dengan masyarakat pada umumya.
Mereka adalah pengikut ajaran Samin Surosentiko (Saminisme) yang memiliki tatanan adat dan kebiasaan yang khas. Sedulur Sikep adalah masyarakat yang memegang prinsip nilai dan sikap bahwa hidup harus selalu berpegang pada kejujuran dan kebenaran. Prinsip nilai dan sikap tersebut diajarkan dan 
dijalankan sepanjang masa dari satu generasi ke generasi berikutnya. Prinsip nilai dan sikap tersebut berakar dari ajaran Samin. Ajaran Samin ini tidak hanya tersebar di Blora saja, tetapi tersebar pula ke daerah-daerah lainnya, seperti Bojonegoro, Kudus, dan Pati.

Saat ini, daerah yang masih terdapat masyarakat yang menjalankan ajaran Samin dengan jumlah paling banyak, yaitu di Kabupaten Pati yang tersebar di beberapa tempat antara lain di Dukuh Bombong, Dukuh Ngawen, dan Dukuh Galiran. Dukuh Bombong merupakan wilayah yang paling banyak masyarakat Sedulur Sikepnya yaitu sekitar 200 kepala keluarga. Kehidupan mereka tidak terisolasi namun membaur dengan masyarakat pada umumnya. Sebagai masyarakat sikep, mereka hidup bertani, mereka tidak diperkenankan untuk berdagang karena dengan berdagang akan cenderung melakukan ketidakjujuran yang tidak sesuai dengan nilai-nilai yang mereka kukuhi.

Secara umum, bahasa yang mereka pakai adalah bahasa Jawa Ngoko. Namun, jika dibandingkan dengan bahasa Jawa pada umumnya, bahasa yang mereka gunakan memiliki perbedaan. Ketika peneliti pertama kali berkunjung dan berkomunikasi dengan masyarakat sedulur sikep, mereka cenderung menjawab pertanyaan seperlunya. Selain itu, ada juga temuan yang cukup menarik ketika pertanyaan dijawab sesuai dengan logika berpikir, mereka namun terasa aneh menurut logika kita. Salah satu contohnya adalah ketika peneliti menanyakan umurnya berapa, mereka menjawab 'siji kanggo salawase' (satu untuk selamanya). Menurut pemahaman umum, jawaban sedulur sikep tersebut agak membingungkan karena biasanya pertanyaan umur akan dijawab sekian tahun. Setelah ditanyakan lebih jauh ternyata dalam pemahaman masyarakat sedulur sikep, umur itu hanya satu, tapi jika ditanya hitungannya baru akan dijawab sekian tahun. Jadi mereka mengatakan bahwa antara apa yang ditanyakan dan jawaban harus sesuai. Ketika ditanya umur maka akan dijawab umur, namun ketika ditanya hitungan tahun maka akan dijawab tahun. Menurut Setyaningsih (2000) pemahaman dasar masyarakat sikep adalah wong sing ngakoni opo sing ditakoni (orang yang menjawab apa yang ditanyakan).

Fenomena ini menarik dan memiliki relevansi dengan prinsip kerja sama antara penutur dan mitra tutur yang diungkapkan oleh Grice bahwa buatlah sumbangan komunikasi seperlunya sesuai dengan tujuan dan arah pembicarannya (Yule: 1996). Prinsip kerjasama berisi anjuran-anjuran agar peserta tutur mematuhi dalam peristiwa komunikasi yang wajar. Dengan demikian, secara sekilas, cara masyarakat Sedulur Sikep menjawab pertanyaan dari orang luar Sedulur Sikep adalah seperlunya atau sesuai dengan yang ditanyakan dan logika berpikir mereka. Berpijak dari temuan awal yang menggambarkan adanya persepsi dan pemahaman yang berbeda antara orang luar dan masyarakat sedulur sikep sehingga terjadi pelanggaran prinsip kerja sama, penelitian ini akan lebih membahas realisasi prinsip kerja sama dalam percakapan masyarakat sedulur sikep.

Penelitian tentang prinsip kerja sama Grice, telah dilakukan oleh beberapa peneliti sebelumnya. Tiarina (2009) meneliti prinsip kerjasama dalam film kartun avatar. Hasil penelitiannnya menunjukan bahwa ujaran yang dituturkan oleh tokoh dalam film tersebut memenuhi dan melanggar prinsip kerja sama. Peneliti lainnya adalah Savitri, Fuad dan Rusminto (2014) yang melakukan penelitian 
pelanggaran prinsip kerjasama dalam novel Rantau 1 Muara karya Ahmad Fuadi. Dalam penelitian tersebut ditemukan bahwa pelanggaran yang banyak dilakukan oleh tokoh dalam novel tersebut adalah pelanggaran maksim relevansi dan kuantitas.

Perbedaan antara penelitian ini dan penelitian sebelumnya adalah objek penelitiannya. Penelitian sebelumnya objek penelitiannya adalah berupa karya sastra berbentuk visual dan cetak, sedangkan objek penelitian ini mengambil komunitas bahasa yang alami dan nyata dengan ciri khas masyarakat yang khas.

\section{Tindak Tutur}

Tuturan merupakan ujaran yang dihasilkan oleh penutur dalam berbagai peristiwa tutur termasuk dalam percakapan. Mengujarkan tuturan dapat dikategorikan sebagai suatu tindakan, sehingga muncul istilah tindak tutur. Austin (1962) menyatakan bahwa tindak tutur dapat dibagi menjadi tiga komponen yaitu tidak lokusi, tindak ilokusi dan tindak perlokusi. Tindak lokusi merupakan ujaran yang terdiri dari kata-kata dengan struktur tertentu dan makna tertentu. Tindak ilokusi dipandang sebagai tindak tutur yang mengandung maksud dan fungsi atau daya tuturan. Dengan kata lain, melalui tindak lokusi, seseorang dapat menyuruh orang lain melakukan sesuatu dengan tuturan. Tindak perlokusi mengacu pada dampak atau efek tuturan yang dirasakan atau dilakukan oleh mitra tutur.

\section{Prinsip Kerja Sama Grice}

Prinsip kerja sama Grice menunjukkan bahwa pembicara selalu bermaksud untuk bekerja sama ketika berbicara. Salah satu cara untuk bekerja sama adalah dengan menyampaikan informasi yang diperlukan. Grice berdasarkan penelitiannya menyebutkan bahwa dalam sebuah percakapan, antara si pembicara dan si penerima terdapat sebuah prinsip yang mengatur percakapan yang terdapat di dalam peristiwa komunikasi yang disebut dengan Prinsip Kerjasama.

Prinsip kerja sama seringkali diartikan sebagai panduan umum yang melingkupi interaksi percakapan. Prinsip kerja sama membuat kontribusi kita menjadi tepat dalam sebuah percakapan. Prinsip kerja sama yang diungkapkan oleh Grice (1975) terdiri dari empat maksim dengan kriterianya masingmasing:

1. Maksim Kualitas

Maksim kualitas menunjukan bahwa ujaran yang disampaikan dapat dipertanggungjawabkan kebenarannya. Tidak boleh mengatakan sesuatu yang palsu atau yang tidak sesuai dengan kenyataannya.

2. Maksim Kuantitas

Maksim kuantitas menunjukkan bahwa ujaran yang disampaikan itu telah memberikan informasi yang cukup sesuai dengan apa yang ingin diketahui oleh mitra tutur dan tidak memberikan informasi yang tidak diperlukan.

3. Maksim Relasi

Maksim relasi menunjukkan bahwa ujaran yang disampaikan relavan dengan apa yang dibicarakan dalam percakapan atau sesuai dengan apa yang dimaksud oleh mitra tutur.

4. Maksim Cara

Maksim cara berhubungan ujaran yang dituturkan dengan bahasa yang tepat, jelas dan tersusun dan menghindari bahasa yang ambigu dan tidak jelas.

\section{METODE PENELITIAN}

Metode yang digunakan dalam penelitian ini adalah metode deskriptif kualitatif. Metode ini menyarankan 
bahwa penelitian ini dilakukan sematamata hanya berdasarkan fakta yang ada atau fenomena yang memang secara empiris hidup pada penuturnya sehingga yang dihasilkan atau dicatat berupa penilaian bahasa yang biasa dikatakan yang sifatnya seperti potret atau paparan seperti adanya (Sudaryanto:1992). Penelitian ini diarahkan untuk menghasilkan deskripsi yang empiris, objektif, dan sistematis terhadap tuturan Masyarakat Sedulur Sikep.

Sumber data yang digunakan dalam penelitian terdiri dari dua jenis yaitu data primer dan data sekunder. Data primer yang digunakan adalah tuturan dalam percakapan masyarakat Sedulur Sikep dalam beberapa sistuasi komunikasi, sedangkan data sekunder yang digunakan adalah hasil wawancara dengan beberapa tokoh Sedulur Sikep untuk mendapat gambaran secara umum tentang Sedulur Sikep.

Dari sumber data yang telah disebutkan diatas dipilih data-data yang spesifik untuk dianalisis yaitu percakapan antara orang luar sikep dan warga sedulur sikep, percakapan antara warga bukan sikep dan warga sikep, percakapan antara pemuda sedulur sikep dan percakapan antar anggota keluarga sikep.

Untuk mendapatkan data yang diharapkan, metode yang digunakan adalah metode simak. Metode simak atau dengan kata lain adalah metode observasi dilakukan dengan cara meyimak penggunaan bahasa yang dituturkan oleh masyarakat sedulur sikep dalam berbagai setting percakapan. Dalam penerapan metode simak, ada beberapa teknik yang dilakukan yaitu Teknik Simak Libat Cakap yaitu dengan terlibat langsung dengan berpartisipasi dalam tindak percakapan yang dilakukan oleh Sedulur Sikep. Dalam beberapa pengambilan data yang lain Teknik Simak Bebas Libat Cakap digunakan dengan tidak terlibat dalam pembicaran untuk mendapatkan data yang alami. Teknik lain yang dipakai dalam pengumpulan data dalam penelitian ini adalah teknik rekam dan catat. Teknik rekam ini dilakukan dengan menggunakan alat perekam berupa voice recoder dan juga telepon pintar. Proses perekaman ini dilakukan sedemikian rupa sehingga tidak mengganggu kewajaran dalam percakapan yang dilakukan. Teknik catat dilakukan pada saat melakukan percakapan dan juga dilakukan pada saat mentranskripsi hasil rekaman.

\section{HASIL DAN PEMBAHASAN}

Penerapan prinsip kerjasama dalam percakapan masyarakat sedulur sikep meliputi pemenuhan prinsip kerjasama dan penyimpangan prinsip kerja sama. Situasi percakapan yang dianalisis terdiri dibagi menjadi tiga yaitu percakapan antara orang luar sikep dan warga sedulur sikep, percakapan antara warga bukan sikep dan warga sikep, serta percakapan antar anggota keluarga warga sedulur sikep.

\section{Percakapan antara Orang Luar Sikep dan Warga Sedulur Sikep}

Yang dimaksud dengan orang luar sedulur sikep adalah para mahasiswa Universitas Diponegoro yang sedang mengadakan kunjungan ke masyarakat Sedulur sikep. Percakapan ini dilakukan oleh seorang mahasiswa (P1) dengan sepasang kakek (P2) dan nenek (P3). Berikut adalah percakapannya:

P1 : "Mbahe niku yuswa pinten? Yuswane itungane pinten taun?"

("Mbah usianya berapa?

Maksudnya usianya berapa tahun ?")

P2 : "Ah yo ra ngerti. Itungane tiyang mriki niki umur siji kanggo 
selawase Ah mbuh. Pas jaman jepang.."

("Ah ya tidak tahu. Hitungan usia orang sini itu satu untuk selamanya. Ah tidak tahu. Waktu jaman jepang...")

P3 : "Mbake ini rung genah Jepang kok. Wong aku wae rung nggenah opo maneh mbake iki piro..."

("Mbaknya ini belum mengerti Jepang. Saya saja belum mengerti apalagi mbaknya ini ..." [DP 1]

Dalam percakapan tersebut P1 menanyakan usia pada P2 dan kemudian dijawab dengan tuturan "itungane tiyang mriki niki umur siji kanggo selawase" yang artinya adalah usia yang dimilikinya itu hanya satu yaitu satu untuk selamanya. Jawaban P2 tersebut memenuhi maksim kuantitas karena menjawab sesuai dengan yang dibutuhkan. Tetapi dibalik pemenuhan maksim kuantitas tersebut, terdapat pelanggaran terhadap maksim cara karena memberi pernyataan yang samarsamar dan ambigu. Maksudnya adalah tidak adanya kepastian jawaban yang diberikan. Umumnya jika pertanyaan "Mbahe niku yuswa pinten?" dilontarkan maka jawaban yang muncul merujuk pada hitungan tahun misalnya 80 tahun. Kemudian pernyataan P2 ditanggapi oleh P3 dengan tuturan "Mbake ini rung genah Jepang kok. Wong aku wae rung nggenah opo maneh mbake iki piro...". Tanggapan P3 tersebut memenuhi maksim relasi, karena tanggapannya sesuai dengan apa yang sedang dibicarakan.

\section{Percakapan antara Warga Bukan Sikep dan Warga Sikep \\ Yang dimaksud warga bukan} Sikep adalah warga yang sama-sama tinggal di Desa Baturejo, Sukolilo-Pati tetapi bukan penganut ajaran saminisme. Percakapan antara warga bukan sikep dan warga sikep dapat ditemukan di tempat jualan sayur. Pedagang sayur adalah warga bukan sikep sedangakan pembelinya adalah warga sikep. Warga sikep tidak ada yang menjadi pedangan, karena menurut ajarannya orang sikep tidak diperbolehkan untuk berdagang atau berjualan karena prinsip hidup yang memegang teguh kejujuran. Berikut adalah data percakapannya:

P1 : "Lawuhe opo buk?" (Lauknya apa buk?)

\section{P2 :"Lawuhe iwak gereh, iwak} meniran karo sego langgi."

("Lauknya ikan asin, ikan meniran dan nasi langgi) [DP2]

P1 adalah pembeli dan $\mathrm{P} 2$ adalah penjual. P1 menyakan lawuhe opo buk? Kemudian P2 menjawab "Lawuhe iwak gereh, iwak meniran karo sego langgi". P2 memberikan pernyataan bahwa lawuhe disini berarti makanan untuk lauknya. Dia menyatakan bahwa lauk yang dia jual adalah sejenis ikan asin dan nasi langgi. Tuturan tersebut memenuhi maksim kualitas, cara dan relasi karena penjual menjawab dengan pernyataan sesuai dengan fakta yang ada dan sesuai dengan apa yang ditanyakan oleh pembeli tetapi melanggar maksim kuantitas karena menambahkan informasi yang tidak perlu yaitu dengan menyebutkan nasi langgi. Nasi langgi bukan merupakan lauk tapi merupakan makanan utama, penjual menambahkan tuturan tersebut dengan harapan pembeli mau membeli nasi langgi yang dijualnya. Data percakapan selanjutnya adalah sebagai berikut:

P1 : "Iki opo? Lha iwak pitike isih rak?"

("ini apa? ayamnya masih tidak?")

P2 : "Niku iwak ri, iwak gereh. Iwak pitike entek."

("Itu ikan ri, ikan asin. Ayamnya habis"). [DP3]

Data percakapan di atas memenuhi memenuhi maksim kuantitas, kualitas, 
relasi dan cara karena tuturan $\mathrm{P} 2$ telah menunjukan pemberian informasi sesuai dengan yang dibutuhkan dan juga penjual memberikan pernyataan yang sudah terbukti kebenarannya serta dengan pilihan kata yang tepat. Data percakapan berikutnya adalah sebagai berikut:

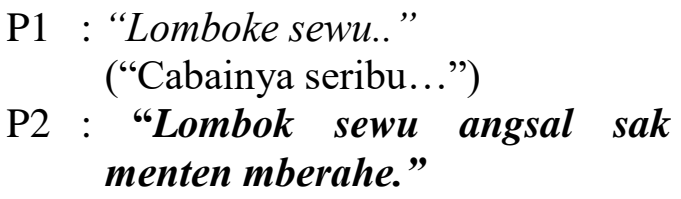

("Cabai seribu dapat banyak") [DP4]

Tuturan "lombok sewu angsal sak menten mbrehe "diujarkan oleh P2 atau penjual ketika melayani pembelian cabai seribu rupiah. Tuturan tersebut berfungsi untuk memberikan informasi bahwa cabai itu murah sehingga dengan uang seribu rupiah, pembeli akan mendapatkan jumlah yang cukup banyak. Tuturan tersebut memenuhi maksim kualitas dan relasi karena memberikan informasi dengan sebenarbenarnya, tetapi melanggar maksim kuantitas karena memberikan pernyataan yang terlalu panjang dan bertele-tele.

\section{Percakapan antara Pemuda Sedulur Sikep}

Para pemuda sikep biasanya memiliki waktu untuk srawung atau berkumpul. Mereka membicarakan tentang segala hal yang berhubungan dengan desanya ataupun dengan berita yang sedang hangat untuk dibicarakan. Berikut adalah data-data percakapan yang dilakukan antar pemuda sedulur sikep:
P1 :"Semangkaem mbok tinggal thenguk-thenguk neng omah ngko nek di gremeti uler yo."
("Semangka kamu kalau ditinggal di rumah di kerumuni ulat.")
P2 : "Semongko ra ono uler."
("Semangka tidak ada ulatnya.") [DP 5]

Percakapan diatas dilakukan oleh 2 pemuda sikep yang berbicara tentang tanaman semangka yang ada di sawah. Nanti takutnya kalau ditinggal kumpulkumpul, tanaman semangkanya dikerumuni ulat. Pada dasarnya, tuturan yang diujarkan itu merupakan kalimat basa-basi untuk membuka suatu percakapan. Pada tuturan "semongko ra ono uler", yang diujarkan oleh P1 kepada P2 berfungsi untuk memberikan informasi kepada P2 bahwa tanaman semangka itu tidak terdapat ulat.

Tuturan tersebut memenuhi maksim hubungan karena terdapat adanya hubungan antara pernyataan semongko ra ono uler dengan pernyataan sebelumnya dan juga memenuhi maksim kulitas karena berbicara sesuai fakta. Selain itu, tuturan tersebut memenuhi maksim kuantitas karena memberikan informasi sesuai dengan yang dibutuhkan. Namun, tuturan tersebut melanggar maksim cara karena mengandung ambigu. Ambigu yang dimaksud adalah antara buah semangka pada umumnya atau tanaman semangka yang ada di sawah. Data percakapan selanjutnya adalah:

P1 : "Sing ping pindone ngono kae uler mati dak gelem ngguwak, iseh nong timbo."

("Yang kedua ulat yang mati itu tidak mau membuang, masih di ember") P2 : "Uler sangger keno banyu $i$

("Ulat kalau kena air pasti mati")

P1 : "Uler nong plastik gwedi-gwedi kok di glumpukno."

("Ulat besar - besar yang ada di plastik kok dikumpulkan) [DP 6]

Tuturan P2 "uler sangger keno banyu $i$ mati" memberikan tanggapan atas tuturan P1. P2 memberikan informasi bahwa jika ulat ditaruh di dalam air maka akan mati. Tuturan P2 ini memenuhi maksim kualitas karena 
memang faktanya seperti itu ulat akan mati jika terkena air. Namun, tuturan ini melanggar maksim hubungan karena yang dimaksud oleh P1 itu bukan itu melainkan mengapa ulat-ulat mati tidak ada yang mau membuang hanya dikumpulkan saja. Hal ini terlihat dari tuturan P1 yaitu "Uler nong plastik gwedi-gwedi kok di glumpukno.". Tuturan P1 tersebut untuk lebih menjelaskan mengenai apa yang dia maksudkan.

\section{Percakapan antar Anggota Keluarga Sikep}

Dalam percakapan antar keluarga, topik yang dibahas adalah rencana panen padi. Penutur yang terlibat terdiri dari tiga orang yaitu seorang ayah (P1), anak (P2), dan anak menantunya (P3). Mereka sedang bercakap-cakap tentang bagaimana teknis pelaksanaan panen padi yang akan mereka lakukan. Berikut ini percakapannya:

P3 : "Wong nem?"

("Enam orang?")

P1 : "Ngene po nduk arahku ki,"

("Kalau menurut hemat saya begini")

P2 : "Maksudku ki ngene loh, sing ngusungi gabah.."

("Maksud saya begini, yang akan memindahkan gabah..")

P1 : "Maksude ki sing ngusungi gabah ping pindhone, ngko nek pomone wedok lanang, ngko mandak ora rampung."

("Maksudnya yang akan memindahkan gabah kedua kalinya, nanti kalau misalnya perempuan dan laki-laki, malah tidak akan rampung.)

P3 : "Kono yo ono wonge lanang sing apeh ngewangi."

("Disana juga ada orang yang akan membantu.") [DP 7]

Percakapan di atas berisi pertimbangan berapa banyak orang yang akan diikutsertakan dalam memanen padi. Pada tuturan "Maksude ki sing ngusungi gabah ping pindhone, ngko nek pomone wedok lanang, ngko mandak ora rampung.", P1 mengeluarkan gagasannya bahwa kehadiran wanita dan pria akan membuat pelaksanaan menjadi tidak lancar. Dalam pernyataan ini, P1 melanggar maksim kuantitas. Pelanggaran ini terjadi karena pada pertanyaan P3 dan P2 yang menanyakan akan berapa banyak orang yang terlibat dalam pelaksanaan panen, tidak ditanggapi oleh P1 dengan memberikan jawaban berdasarkan pertanyaan. Justru P1 memberikan penjelasan lain yang tidak terkait dengan pertanyaan P2 dan P3. Dalam pernyataannya, P1 juga tidak menyebutkan jumlah orang yang akan diikutkan memanen padi. Selain melanggar maksim kuantitas, P1 juga melanggar maksim relasi atau hubungan antara pernyataan sebelumnya dengan apa yang dikatakannya. Hal ini dikarenakan tidak ada korelasi antara pernyataan P1 dengan P2 dan P3. Meskipun demikian, P1 memenuhi maksim kualitas. Hal ini karena P1 meyakini apa yang dia katakan benar dan sesuai dengan kenyataan. P1 sangat yakin jika keberadaan wanita dalam pelaksanaan memanen padi akan membuat suasana semakin ricuh. Dalam maksim cara, P1 memenuhi prinsip tersebut. Tuturan P1 memenuhi prinsip bagaimana menghasilkan ujaran yang dapat dimengerti dan tidak menimbulkan penafsiran ganda. Data percakapan selanjutnya adalah sebagai berikut:

P2 : "Sing ngusungi montor kepenak sik. Ngko maksude ki ono sing ngusungi montor, ono sing..." ("Yang memindahkan menggunakan motor akan nyaman. Nanti maksudnya ada yang memindahkan pakai motor, ada yang...")

P1 : "halah, wes rak sah kakean ruwet!" 
"Kepenak langsung "Nyet", wes langsung tekan ratan koyok ndek mben."

("Sudah tidak usah bingungbingung. Enakan langsung saja, langsung sampai jalan seperti yang dulu.")

P3 : "Ki mau motore ki langsung tutuk ratan. (4) Ngengkel ki. Berarti watake iso Mbah, di tleser ki. Asal ki iso tuk kono lah. Neng Kidul. " ("Ini tadi motornya langsung bisa sampai di jalan. Gak percaya dia. Mungkin bisa Mbah. Asal bisa sampai sana, sampai selatan.") [DP 8]

Dalam DP 8 di atas, P1 menegaskan teknis yang akan dilaksanakan sama seperti yang sudah dilakukan sebelumnya. Tuturan tersebut memenuhi maksim kuantitas dan kualitas karena secara tegas P1 menjawab dan memutuskan apa yang harus dilakukan pada saat panen padi. Pernyataan ini dipertegas dengan penggunaan keterangan waktu "koyok ndek mben" yang berarti "seperti yang dulu". Hal ini jelas sekali bahwa tuturan P1 memenuhi maksim kualitas, karena P1 sangat yakin apa yang diujarkan merupakan suatu fakta yang sudah terjadi dan jelas kebenarannya. Dalam pemenuhan maksim relasi dan cara, ujaran P1 juga memenuhinya karena terdapat relasi yang jelas antara pernyataan $\mathrm{P} 1$ dengan $\mathrm{P} 2$ sebelumnya. P1 menjawab dan mengomentari gagasan yang dilontarkan oleh P2. Tuturan P1 juga dapat dipahami dengan baik tanpa ada ketaksaan makna di dalamnya. Selain itu tuturan P1 juga memenuhi maksim kuantitas karena menjelaskan dengan tegas tanpa berteletele.

Menanggapi keputusan yang disampaikan oleh P1, P3 menceritakan keadaan yang sudah terjadi. Penggunaan kata ' $k i$ ' dan 'mau' yang dalam bahasa
Jawa diterjemahkan menjadi 'ini' dan 'tadi' menunjukkan keterangan waktu. P3 ingin menekankan bahwa apa yang disampaikannya merupakan bentuk sebuah fakta dengan adanya penggunaan keterangan waktu. Tuturan tersebut memenuhi empat maksim dalam prinsip kerjasama yang dikemukakan oleh Grice. Maksim kuantitas dan kualitas terpenuhi karena P3 ingin menjelaskan dan menegaskan apa yang disampaikan oleh P1. Dalam hal kualitas, P3 sangat yakin apa yang disampaikannya benarbenar sebuah kenyataan karena kejadian ini benar-benar telah terjadi. Pemenuhan maksim hubungan dapat dengan jelas dilihat karean adanya kata yang sama pada ujaran P1 dan P3, yakni 'ratan' yang berarti 'jalan'. Kata ini sama-sama muncul dalam ujaran kedua penutur ini. Sehingga, relasi antara P1 dan P3 samasama terpenuhi. Dalam hal maksim cara, ujaran P3 ini dapat dimengerti dengan baik tanpa kesamaran pemahaman. Data percakapan selanjutnya disajikan sebagai berikut:

P3 : "Pokok men ngko ditiliki sek, ngko goleko tleser wae."

("Pokoknya nanti dilihat dulu, nanti kamu cari tleser saja.")

P1 : "Iyo gampang, pokokmen masalah tleser mberah.”

("Iya gampang, pokoknya untuk urusan tleser banyak sekali.")

[DP 9]

Data percakapan di atas memenuhi keempat maksim prinsip kerjasama. Maksim kuantitas dipenuhi karena ujaran P1 tersebut cukup singkat dalam menegasakan apa yang sudah dikemukakan oleh P3 dalam ujaran sebelumnya. Dan P1 sangat yakin akan pernyataan yang diucapkannya merupakan fakta dan cukup benar kenyataanya. Maksim hubungan juga terpenuhi karena adanya kata yang sama dalam ujaran P1 dengan kalimat P3 sebelumnya. Indikasi kata yang sama 
yakni kata "tleser" pada kedua kalimat. Sehingga, relasi kedua ujaran terkait. Begitu juga maksim cara, jelas sekali bahwa ucapan P1 ini tidak menimbulkan ketaksaan makna. Data percakapan selanjutnya adalah sebagai berikut:

P3 : "Maksude lak wonge ngko sing kon ngarit wae sik rasan."

(Maksudnya kan nanti kan orangnya disuruh memotong rumput dulu.")

P2 : "Ngarite kesuen, ha nak wong kene kan ngarite kesuen.”

(Menyabitnya terlalu lama, kan kalau orang sini mereka menyabitnya kelamaan,") [DP 10]

Pada data percakapan di atas, P2 memberikan penjelasan terhadap ujaran P3 yang menyatakan bahwa penduduk di sekitar rumahnya tidak bisa menyabit dengan cepat dan cenderung berlamalama. Berdasarkan ujaran sebelumnya, tuturan P2 ini memberikan penjelasan lebih dari yang dibutuhkan oleh P3 sehingga melanggar maksim kuantitas. Setelah memberikan tanggapan pada apa yang diujarkan oleh P3 dengan klausa "ngarite kesuen", P2 menambahi dengan penjelasan berupa "ha nak wong kene kan ngarite kesuen". Tuturan kedua yang dilontarkan melanggar maksim kuantitas. Jika dilihat dari maksim kualitas, ujaran P2 ini sangat yakin dengan apa yang diucapkannya yaitu bagaiman kemampuan penduduk disekitarnya perihal menyabit rumput. Pada klausa yang pertama, tuturan P2 ini memenuhi maksim relasi. Namun, karena klausa yang kedua merupakan penjelasan yang tidak dibutuhkan oleh P3, maka klausa yang kedua melanggar maksim relasi. Ujaran P2 ini memenuhi maksim cara, karena kalimat P2 dapat dipahami dan tidak menimbulkan penafsiran yang ganda akan tetapi hanya bertele-tele.

Berdasarkan temuan pada datadata percakapan di atas dapat diketahui bahwa percakapan masyarakat sedulur sikep sebagian besar memenuhi prinsip kerja sama Grice diantaranya maksim kuantitas, kualitas, relasi dan cara. Seluruh tuturan yang diujarkan dalam percakapan tersebut memenuhi maksim kualitas, karena apa yang mereka katakan sesuai dengan fakta yang terjadi di lingkungan mereka. Mereka sama sekali tidak menghasilkan tuturan yang tidak benar atau tidak ada maksud menyembunyikan fakta dalam tuturan mereka karena sifat mereka yang memegang teguh prinsip adat yaitu "kejujuran dan apa adanya".

Tuturan yang dihasilkan orangorang sedulur sikep, pada umumnya memenuhi maksim cara. Tuturan mereka dapat dipahami dengan mudah tanpa menimbulkan ketaksaan makna. Hal ini terkait dengan ciri khas mereka yang menyatakan sesuatu dengan jelas tanpa ada yang ditutup-tutupi. Ini sesuai dengan prinsip mereka yang tidak ingin menyusahkan orang lain.

Pada beberapa tuturan sedulur sikep terdapat beberapa yang melanggar maksim kuantitas dikarenakan sifat tuturan mereka yang fungsinya untuk menegaskan yang dibuktikan dengan adanya pengulangan kembali kalimat atau kata yang sudah diucapkan. Pelanggaran yang dilakukan bukan berupa "basa-basi" seperti yang dilakukan orang jawa kebanyakan karena prinsip orang-orang sedulur sikep adalah tidak ada pembicaraan yang siasia atau selalu langsung pada poin pembicaraan.

Selain itu, pemenuhan maksim relasi banyak ditemukan dikarenakan dalam kewajaran berkomunikasi diperlukan saling pemahaman antara penutur dan mitra tutur sehingga antara yang dituturkan dan tanggapan dapat saling berhubungan. 


\section{PENUTUP}

Realisasi prinsip kerjasama Grice, pada percakapan masyarakat sedulur sikep memenuhi maksim-maksim kerjasama Grice di antaranya : maksim kualitas, maksim kuantitas, maksim relasi dan maksim cara. Tuturan yang memenuhi maksim-maksim prinsip kerjasama Grice mengimplikasikan bahwa tuturan yang diungkapkan oleh masyarakat sedulur sikep sesuai dengan fakta, relevan dan singkat, sedangkan realisasi prinsip kerjasama yang melanggar maksim-maksim prinsip kerjasama diantaranya: maksim kuantitas, maksim relasi dan maksim cara. Tuturan yang melanggar maksimmaksim prinsip kerjasama Grice mengimplikasikan bahwa tuturan yang diungkapkan oleh masyarakat sedulur sikep terkadang mereka sering melakukan pengulangan kembali dalam kalimat sebagai bentuk penegasan atas pernyataan yang diucapkan, ambigu, informasi yang disampaikan tidak relevan.

\section{DAFTAR PUSTAKA}

Austin, J.L. (1962) How to Do Things with Words.Oxford:Oxford University Press.

Grice,H.P. (1975) Logic and Conversation. (dalam Syntax and Semantics, Vol.3, Speech Acts, diedit oleh Peter Cole dan Jerry L. Morgan.New York:Academic Press 1975, 41-58)

Savitri, R., Fuad, M. \& Rusminto, N.E. (2014) Pelanggaran prinsip kerjasama dalam novel Rantau 1 Muara karya Ahmad Fuadi. Jurnal J-simbol (bahasa, sastra dan pembelajarannya).

Sudaryanto. (1993) Metode dan Aneka Teknik Analisis Bahasa. Yogyakarta: Duta Wacana

Tiarina, Y. (2009) Prinsip kerjasama dalam film kartun avatar. Jurnal Bahasa dan Seni Vol 11. No.1 (6270) 